\title{
Formation of isocyanide complexes via acylation of diaminocarbene complexes
}

\author{
Jian-Yang Cho a, Chi-Li Chen a, Tung-Ying Hsieh a, Fu-Mei Kiang ${ }^{\text {b }}$, Gene-Hsiang Lee a, \\ Shie-Ming Peng ${ }^{a}$, Shiuh-Tzung Liu ${ }^{\text {a, } *}$ \\ a Department of Chemistry, National Taiwan University, Taipei, Taiwan 106, ROC \\ ${ }^{\mathrm{b}}$ Department of Pharmacy, China Medical College, Taichung, Taiwan, ROC
}

Received 16 December 1997; received in revised form 25 February 1998

\begin{abstract}
Treatment of cyclic diaminocarbene tungsten complexes $(\mathrm{CO})_{5} \mathrm{~W}=\mathrm{CNRCH}_{2} \mathrm{CH}_{2} \mathrm{~N} H[\mathrm{R}=\mathrm{Ph}$, Et] with acylating agents resulted in the formation of isocyanide complexes via the cleavage of $\mathrm{C}-\mathrm{N}$ bond. Crystal structure of $(\mathrm{CO})_{5} \mathrm{WCN}\left(\mathrm{CH}_{2}\right)_{2} \mathrm{~N}(\mathrm{Ph}) \mathrm{COPh} 2 \mathrm{a}$ was determined. (C) 1998 Elsevier Science S.A. All rights reserved.
\end{abstract}

Keywords: Diaminocarbene complexes; Acylation; Isocyanide; Tungsten

\section{Introduction}

The diaminocarbene species known as a 'bottleable carbene' has received much attention recently [1-5]. Such carbenes can be considered typical nucleophilic ligands which allow them to become a good $\pi$-donor towards various metal and non-metal ions [5-8]. In the structural analysis, the distance of $\mathrm{C}_{\text {(car- }}$ bene) $-\mathrm{N}$ appears to be intermediate between typical single-bond and double-bond lengths (Scheme 1), indicating the resonance stabilization by the better donor nitrogen atoms. It is also known that aminocarbene complexes with primary or secondary amine moieties can react with acylating agents in various fashions. For example, aminocarbene $(\mathrm{CO})_{5} \mathrm{Cr}=\mathrm{C}\left(\mathrm{NH}_{2}\right) \mathrm{R}$ can be converted to 2-azaallenyl

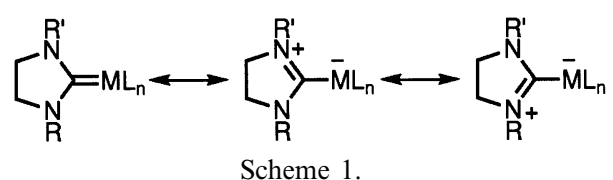

* Corresponding author. Fax: + 886223636359. complexes via the reaction of $\mathrm{NH}_{2}$ group with acyl chloride [9], whereas the $N$-acylated product was obtained when $(\mathrm{CO})_{5} \mathrm{Cr}=\mathrm{C}(\mathrm{NHR}) \mathrm{Ar}$ reacted with acetic anhydride in the presence of base [10]. In the previous work, we were able to prepare the stable diaminocarbene group 6 metal complexes 1 with secondary amine moiety in the molecule [11]. Here we report the reaction of cyclic diaminocarbene complexes with acylating agents to yield the corresponding isocyanide species.<smiles>CCP[PbH2]</smiles>

\section{Results and discussion}

Instead of granting the $N$-acylated carbene product, treatment of diaminocarbene 1a with benzoyl chloride in the presence of pyridine at reflux for $12 \mathrm{~h}$ resulted in the formation of the isocyanide complex $2 \mathbf{a}$ (Scheme 2). 


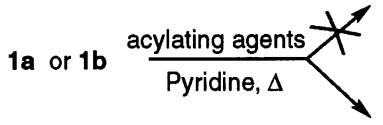

2a $R=P h R^{\prime}=P h$

2b $\mathrm{R}=\mathrm{Et} \mathrm{R}^{\prime}=\mathrm{Ph}$

2c $\mathrm{R}=\mathrm{Et} \quad \mathrm{R}^{\prime}=\mathrm{CH}_{3}$

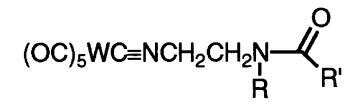

Complex 2a was characterized by both spectral and X-ray crystal structural analyses. The infrared spectrum for 2a showed a characteristic band at $2176 \mathrm{~cm}^{-1}$, which is consistent with the coordinated isocyanide stretching absorption, and metal-carbonyl stretching frequencies at $2069,1947 \mathrm{~cm}^{-1}$. The ${ }^{13} \mathrm{C}$-NMR chemical shift at $\delta 144.6$ is typical for the coordinated isocyanide which provides another information of the structure proposed. Nevertheless, the structure of 2a was further confirmed by single-crystal X-ray diffraction and the ORTEP plot is presented in Fig. 1 [12].

As expected, the tungsten atom is in an octahedral environment, since it is bound to an isocyanide and five carbonyl ligands. The $\mathrm{W}$-ligands distances are similar to those reported for analogous $(\mathrm{CO})_{5} \mathrm{WCNR}$ species [13]. All bond distances and bond angles are in normal ranges as illustrated in Fig. 1. The distance of tungsten to isocyanide ligand [W-C6 2.120(6) $\AA$ ] is similar to that of $\left.\mathrm{CH}_{3} \mathrm{C}_{2} \mathrm{CH}_{2} \mathrm{NCW}(\mathrm{CO})_{5}\right]_{3}[2.08(2) \AA]([13] \mathrm{a})$. The distance of carbonyl ligand trans to isocyanide [W-C3 2.001(8)] appears to be shorter than those cis to it. The distance of C6-N1 $[1.136(8) \AA]$ is attributed to the $\mathrm{C} \equiv \mathrm{N}$ in the coordinated isocyanide.

Conversion of diaminocarbene to the isocyanide complex appears to be a trend in such tungsten carbene

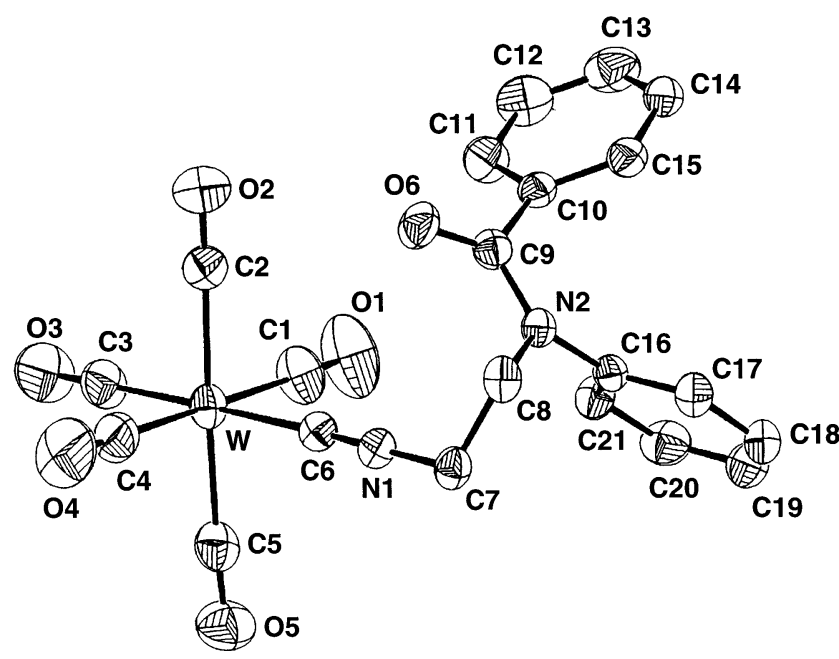

Fig. 1. ORTEP Plot of 2a. W-C6 2.120(6), W-C1 2.028(9), W-C2 2.027(8), W-C3 2.001(8), W-C4 2.041(9), W-C5 2.031(8), W-C6-N1 177.8(5), C1-W-C6 90.0(3), C6-W-C3 179.3(3).

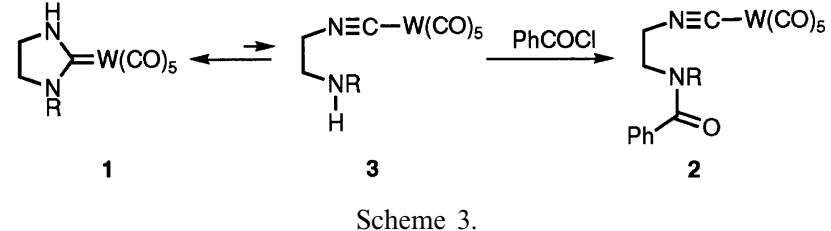

complexes. Both reactions of $\mathbf{1 b}$ with benzoyl chloride and $\mathbf{1 b}$ with acetic anhydride provide the corresponding isocyanide complexes $\mathbf{2 b}$ and $\mathbf{2 c}$, respectively [14]. Other acylating agents such as acetyl bromide or acetyl chloride provide the same result whereas di-tert-butyl dicarbonate $(t-\mathrm{BuOCO})_{2} \mathrm{O}$ does not react with diaminocarbene complexes at all. In the previous study, we have found that the deprotonation of $\mathbf{1 a}$ or $\mathbf{1 b}$ with sodium hydride accompanied with alkylation yielded the $N$-alkylated carbene complexes [11]. However, deprotonation of $\mathbf{1 a}$ by $n$ butyllithium followed by the treatment of benzoyl chloride at r.t. resulted in the recovery of the starting material, whereas the isocyanide product $\mathbf{2 a}$ was obtained when the reaction was carried out at refluxing temperature.

It is reported by Dötz and coworkers that the $N$-acylated aminocarbene complexes can be obtained effectively by the treatment of carbene complexes with acylating agents in the presence of dimethylaminopyridine(DMAP) as the catalyst [10]. However, attempts to prepare the $N$-acylated diaminocarbene of 1 under Dötz conditions or even under refluxing THF solution failed and the starting material was recovered. This result indicates that the reactivity of diaminocarbene complexes is quite different from a simple aminocarbene species such as $(\mathrm{CO})_{5} \mathrm{CrC}(\mathrm{NHR}) \mathrm{Ar}$.

Formation of the isocyanide complex is presumably via the ring-opening of the cyclic carbene to form an isocyanide intermediate $\mathbf{3}$ followed by the acylation of secondary amine to yield the product (Scheme 3). The first step involves the cleavage of $\mathrm{C}-\mathrm{N}$ bond, which is the reversed process of the addition of amine to isocyanide moiety, a known approach to prepare diaminocarbenes [11]. Unfortunately, it is not possible to detect the intermediate 3 via monitoring the sample of 1 by NMR spectrometer even at higher temperature indicating that the carbene species is thermodynamically more stable than the isocyanide form. However, the amine moiety of 3 is once acylated, the nitrogen atom becomes less nucleophilic and is not able to form the carbene species. In this investigation, the available data indicates that the stable class of diaminocarbene complex can undergo the cleavage of $\mathrm{C}-\mathrm{N}$ bond thermally to form the isocyanide functionality.

\section{Acknowledgements}

We thank the National Science Council of the Republic of China for financial support (NSC87-2113M002-10). 


\section{References}

[1] N. Wiberg, Angew. Chem. Int. Ed. Engl. 7 (1968) 766.

[2] A.J. Arduengo III, J.R. Goerlich, W.J. Marshall, J. Am. Chem. Soc. 117 (1995) 11027, and references therein.

[3] R.W. Alder, P.R. Allen, M. Murray, A.G. Orpen, Angew. Chem. Int. Ed. Engl. 35 (1996) 1121.

[4] D. Enders, K. Breuer, J. Runsink, J.H. Teles, Liebigs Ann. (1996) 2019.

[5] M. Regitz, Angew. Chem. Intl. Ed. Engl. 35 (1996) 725, and references therein.

[6] (a) U. Kernbach, M. Ramm, P. Luger, W.P. Fehlhammer, Angew. Chem. Int. Ed. Engl. 35 (1996) 310. (b) N. Kuhn, H. Bohnen, J. Fahl, D. Bläser, R. Boese, Chem. Ber. 129 (1996) 1579. (c) D. Enders, H. Gielen, G. Raabe, J. Runsink, J. H. Teles, Chem. Ber. 129 (1996) 1483. (d) A. J. Arduengo III, R. Krafczyk, W. J. Marshall, R. Schmutzler, J. Am. Chem. Soc. 119 (1997) 3381. (e) H. Schumann, M. Glanz, J. Winterfeld, H. Hemling, N. Kuhn, T. Kratz, Chem. Ber. 127 (1994) 2369. (f) J.A. Chamizo, P.B. Hitchcock, H.A. Jasim, M.F. Lappert, J. Organomet. Chem. 451 (1993) 89, and references therein.

[7] (a) W.A. Herrmann, M. Elison, J. Fischer, C. Köcher, G.R.J. Artus, Chem. Eur. J. 2 (1996) 772. (b) W.A. Herrmann, M. Elison, J. Fischer, C. Köcher, G. R.J. Artus, Angew. Chem. Int. Ed. Engl. 34 (1995) 2371, and references therein.

[8] M.F. Lappert, P.L. Pye, J. Chem. Soc. Dalton Trans (1977) 1283.

[9] R. Aumann, S. Althaus, C. Krüger, P. Betz, Chem. Ber. 122 (1989) 357.

[10] (a) K.H. Dötz, D. Grotjahn, K. Harms, Angew. Chem. Int. Ed. Engl. 28 (1989) 1384. (b) D.B. Grotjahn, F.E.K. Kroll, T.
Schäfer, K. Harms, K.H. Dötz, Organometallics 11 (1992) 298.

[11] C.-Y. Liu, D.-Y. Chen, G.-H. Lee, S.-M. Peng, S.-T. Liu, Organometallics 15 (1996) 1055.

[12] 2a: a light yellow crystalline solid $(48 \%)$, m.p. $125-126^{\circ} \mathrm{C}(\mathrm{dec})$; ${ }^{1} \mathrm{H}-\mathrm{NMR}\left(200 \mathrm{MHz}, \mathrm{CDCl}_{3}\right) \delta 7.33-7.05(\mathrm{~m}, 10 \mathrm{H}, \mathrm{Ar}-\mathrm{H}), 4.24$ $(\mathrm{t}, J=5.4 \mathrm{~Hz}, 2 \mathrm{H}), 4.08(\mathrm{t}, J=5.4 \mathrm{~Hz}, 2 \mathrm{H}) ;{ }^{13} \mathrm{C}-\mathrm{NMR} \delta 195.8$, $194.2(\mathrm{~W}-C \mathrm{O}), 171.0,144.6(\mathrm{~W}-C \mathrm{~N}-), 143.0,134.7,130.3$, 129.7, 128.9, 127.4.127.3, 49.6, 42.2. Elemental Anal. Calcd for $\mathrm{C}_{21} \mathrm{H}_{14} \mathrm{~N}_{2} \mathrm{O}_{6} \mathrm{~W}$ : C, 43.93; H, 2.46; N, 4.88. Found: C, 43.48; H, 2.51; N, 4.91.; Crystal data: $\mathrm{C}_{21} \mathrm{H}_{14} \mathrm{~N}_{2} \mathrm{O}_{6} \mathrm{~W}, F w=574.2$, Monoclinic $P 2_{1} / n, a=12.975(3) \AA, b=13.417(3) \AA ⿻$ 员, $c=13.590(3) \AA$, $\beta=113.56(2)^{\circ}, V=2168.4(8) \AA^{3}, Z=4, D_{\text {Calcd }}=1.759 \mathrm{~g} \mathrm{~cm}^{-3}$, $F(000)=1100, \mu\left(\mathrm{Mo}-\mathrm{K}_{\alpha}\right) 54.763 \mathrm{~cm}^{-1}$, crystal size $0.15 \times$ $0.35 \times 0.50 . T=298 \mathrm{~K}, \mathrm{CAD} 4$ diffractometer, 3811 unique reflections [2693 observed, $I>2.0 \sigma(I)], R \mathrm{f}=0.029, R \mathrm{~W}=0.030$. $\mathrm{GoF}=1.48$.

[13] (a) F.E. Hahn, M. Tamm, J. Organomet. Chem. 410 (1991) C9. (b) W.P. Fehlhammer, G. Zinner, G. Beck, J. Fuchs, J. Organomet. Chem. 379 (1989) 277. (c) M. Fritz, D. Rieger, E. Bär, G. Beck, J. Fuchs, G. Holzmann, W.P. Fehlhammer, Inorg. Chim. Acta, 198 (1992) 513.

[14] 2b: $\operatorname{IR}\left(\mathrm{CH}_{2} \mathrm{Cl}_{2}\right) 2171 \mathrm{~cm}^{-1}\left(v_{\mathrm{C} \equiv \mathrm{N}}\right), 2069,1946 \mathrm{~cm}^{-1}\left(v_{\mathrm{CO}}\right), 1641$ $\mathrm{cm}^{-1}\left(v_{\mathrm{N}-\mathrm{CO}}\right) ;{ }^{1} \mathrm{H}-\mathrm{NMR}\left(200 \mathrm{MHz}, \mathrm{CDCl}_{3}\right) \delta 7.5-7.23(\mathrm{~m}, 5$ $\mathrm{H}), 4.05(\mathrm{t}, J=6.0 \mathrm{~Hz}, 2 \mathrm{H}), 3.73(\mathrm{t}, J=6.0 \mathrm{~Hz}, 2 \mathrm{H}), 3.40(\mathrm{q}$, $J=6.6 \mathrm{~Hz}, 2 \mathrm{H}), 1.17(\mathrm{t}, J=6.6 \mathrm{~Hz}, 3 \mathrm{H}) ;{ }^{13} \mathrm{C}-\mathrm{NMR} \delta 195.7$, $194.1\left(J_{\mathrm{P}-\mathrm{W}}=67 \mathrm{~Hz}\right), 170.8,144.1(\mathrm{~W}-\mathrm{CN}-), 133.4,129.6$, 128.6, 126.0, 45.9, 44.9, 42.2, 14.3. 2c: $\mathrm{IR}\left(\mathrm{CH}_{2} \mathrm{Cl}_{2}\right) 2173 \mathrm{~cm}^{-1}$ $\left(v_{\mathrm{C}=\mathrm{N}}\right), 2065,1944 \mathrm{~cm}^{-1}\left(v_{\mathrm{CO}}\right), 1640 \mathrm{~cm}^{-1}\left(v_{\mathrm{N}-\mathrm{Co}}\right) ;{ }^{1} \mathrm{H}-\mathrm{NMR}$ $\left(200 \mathrm{MHz} \mathrm{CDCl}_{3}\right) \delta 3.92(\mathrm{t}, J=6.0 \mathrm{~Hz}, 2 \mathrm{H}), 3.60(\mathrm{t}, J=6.0$ $\mathrm{Hz}, 2 \mathrm{H}), 3.46(\mathrm{q}, J=6.6 \mathrm{~Hz}, 2 \mathrm{H}), 2.10(\mathrm{~s}, 3 \mathrm{H}), 1.51(\mathrm{t}, J=6.6$ $\mathrm{Hz}, 3 \mathrm{H})$. 